\title{
IMPROVEMENT OF THE TECHNOLOGY OF OBTAINING STABLE (DI)HAPLOID REGENERANTS FROM EMBRYONIC CULTURE OF APOMICTIC SUGAR BEET (BETA VULGARIS) BREEDING MATERIAL WITHOUT THE USE OF COLCHICINE
}

\author{
N. S. Kovalchuk ${ }^{1}$, M. V. Roik ${ }^{1}$, Ya. M. Hadzalo ${ }^{2}$, T. M. Nediak ${ }^{1}$, O. A. Zinchenko ${ }^{1}$ \\ ${ }^{1}$ Institute of Bioenergy Crops and Sugar Beet, NAAS \\ 25, Klinichna Str., Kyiv, 03110, Ukraine \\ ${ }^{2}$ National Academy of Agrarian Sciences, \\ 9, Omelianovych-Pavlenko Str., Kyiv, 01010 Ukraine \\ E-mail:sugarbeet@ukr.net,natalakovalcuk461@gmail.com
}

Received February 18, 2019 / Received April 22, 2019 / Accepted July 19, 2019

\begin{abstract}
Aim. To evaluate the efficiency of inducing generative, reduced parthenogenesis and to better use the differentiating potential of the embryo culture under apomictic seed production in selection materials of sugar beet with cytoplasmic male sterility (CMS), and B) to isolate homozygous lines (dihaploids) without the use of polyploidizing substances. Methods. Apomictic (agamospermous) seed production in apocarpous pollen sterile lines from B. vulgaris subsp. vulgaris var. altissima (sugar beet) using classical so-called Owen sterile cytoplasm and sterile cytoplasm from Beta maritima and Beta patula as sources, was conducted under pollen free conditions and spatial isolation in the greenhouse breeding complex of the Yaltushkivska experimental breeding station (Yaltushki, Ukraine). The specificities of embryonic development of apomictic embryos were studied with the purpose of efficient regulation of the induction of explants in vitro as donors of the culture of immature embryos. Fluorescent flow cytophotometry in combination with the computer program of the Partec Ploidy Analyser PA-2 (Partec GmbH, Germany, now Sysmex), were used to determine the degree of ploidy, enabling the selection of haploid and dihaploid lines in vitro. A genetic method was developed using the expression of morphological marker indices of nuclear genes of anthocyanin coloring $(\mathrm{R}+\mathrm{r}-)$ of regenerant plants in vitro and ploidy determination for differentiation by generative (reduced) parthenogenesis. The sampling technique that took into account the hormonal composition of cultural media and the level of genome ploidy, sample frequency and statistical analysis of the results was determined using the appropriate statistics; the percentage of regenerants, induced by different types of morphogenesis and ploidy in vitro, was determined along with the measurement error to control the accuracy of the selected sampling (number of seed embryos). Results. The selected cultural medium No. 3 , based on the basal medium according to Gamberg et al., 1968 (21), contained 6 BAP $-2 \mathrm{mg} / 1,2.4 \mathrm{D}-0.5 \mathrm{mg} / \mathrm{l}$, gibberellic acid $-0.1 \mathrm{mg} / \mathrm{l}$, which ensured a success rate of 4.4 to $23.3 \%$ of direct regeneration of shoots from the embryo culture, depending on the genotype of donors, and 4-10\% for induction and proliferation of callus. In ten experimental numbers of alloplasmic lines of sugar beet, the incidence of haploids and mixoploids among the regenerants from the embryo culture fluctuated within the wide range of $14.8-62.2 \%$ and exceeded the indices, obtained by other known methods of haploid parthenogamy, which had the values of $3.79-6.25 \%$. Conclusions. The homozygous lines and dihaploids were determined and set apart/stabilized in the process of micropropagation, where the differentiation of clones was made on the basis of total DNA content in interphase nuclei, using information of histograms generated in fluorescent flow cytometry with the Partec Ploidy Analyser PA-II instrumentation. The medium, based on macro- and microsalts according to Gamberg et al., 1968 (21) was found to be the most efficient; it ensured at least partially successful direct regeneration in the culture of embryos within the range of $4.40 \pm 1.29$ to $23.3 \pm 3.45 \%$. The success of direct regeneration of apomictic material depended on the composition of the cultural medium used first and foremost, and to a lesser extent on the stages of embryogenesis from day 12 till day 32, differentiated by the fixation period for seed embryos starting from the beginning of flowering. Homozygous lines were created without polyploidinducing substances due to spontaneous transfer of some cells of haploid regenerant plants to a higher level of ploidy, that can be used in the breeding of sugar beet. Genetic determination of apomictic seed reproduction in alloplasmic lines and pollen free lines of sugar beet and the technologies of inducing dihaploids allow reducing the period of inzucht-crossing considerably to obtain homozygous lines, creating unique material for chromosome engineering and marker-oriented selection with target combinations of genes in homozygous state.
\end{abstract}

Keywords: apomixis (apozygoty), haploids, dihaploids, alloplasmic lines, Beta maritima, ploidy analyzer (PA) Partec.

DOI: https://doi.org/10.15407/agrisp6.02.003

(C) N. S. KOVALCHUK, M. V. ROIK, Ya. M. HADZALO, T. M. NEDIAK, O. A. ZINCHENKO, 2019 


\section{INTRODUCTION}

Apomixis, the reproduction via asexually formed seed, i.e. embryo parthenogenesis from unfertilized cells of the embryo sac, occurs frequently among angiosperms, some species or genera may be completely apomictic, with different ways of seed production for microspecies (biotypes) of the same species [1-3]. Seedlings arising from apomictic seed have the genotype of the maternal parent. Most researchers of apomixis in plants have the opinion that in this case an embryo without pollination and fertilization occurs not due to the combination of generative cells but due to cloning of maternal tissue of a developing seed $[4,5]$. New strategies of genomics have become available for further understanding the key mechanisms of meiosis regulation and parthenogenesis after deciphering the genomes of Arabidopsis, Iris and others [1, 2, 5]. Numerous results of apomixis studies demonstrated a high and confusing level of gene, chromosome, and morphological diversity in the apomictic progeny [6-7]. The embryological studies proved that, depending on the way of forming embryo sacs, the nature of the apomictic embryo development is determined by the type of apomixis: diplospory, apospory, adventive embryony or parthenogenesis $[1,6]$.

In diplospory (generative apospory) the embryo sac developed out of a non-reduced megasporocyte. In some, meiosis may be substituted/followed by mitosis or the second division is absent. The formation of parthenogenetic embryos takes place in diplosporous embryo sacs of the Polygonum-type, these embryos develop to the globular stage and their further development does not take place due to the absence of endosperm formation [6]. Low indices of seed formation are notable for many other species regardless of diplosporous types and this is one of the unsolved problems for application of diplospory/apomixis in (molecular) plant breeding $[1,7$, 8]. In most species, nucellar and integumental embryony is combined with generative parthenogenesis and embryos which get into the embryo sac from outside. A haploid embryo out of reduced cells and an adventive embryo out of somatic cells do occur $[2,6]$.

Some of the main differences in the genetic origin of embryos are as follows:

- different ploidy of embryo sac cells - somatic aposporous and diplosporous (generative aposporous, meiotic ones);

- embryos with a maternal genome in case of adventive embryony or with a recombinant genome when developing from reduced and non-reduced cells of the embryo sac.
Parthenogenesis is the development of an embryo from an unfertilized egg cell. This parthenogenesis can be diploid and haploid. Diploid parthenogenesis takes place in two ways: 1) in embryo sacs without meiosis (diplosporic parthenogenesis or generative apospory, the megagametophyte arises from a cell of the archesporium) and 2) with somatic apospory (somatic aposporous, the megagametophyte arises from some other nucellus cell). Haploid parthenogenesis is observed in reduced embryo sacs, the cells of which were formed due to meiotic division. It was proven that haploid embryos are not capable to grow without diploidy, their share among seedlings is only $1-2 \%$. However, through haploid parthenogenesis haploid embryos in some species with generative apozygoty and new introduced cytoplasm from wild types (for instance, the case in alloplasmic lines of Triticum aestivum), may reach the percentage of $90 \%$ [9].

The practical value of apomixis is substantially due to the possibility of preserving hybrid $(F 1)$ and heterosis properties in economically valuable plants for many years and generations. There is presently a high economic interest and perspective of great benefit for the use of apomixis by leading plant breeding companies of the world (e.g. Syngenta, Pioneer Hi Bred International, Rijk Zwaan Zaadteelt B. V., and others) $[2,4,5]$. Especially high hopes are laid on the methods of molecular genetics and genetic transformation of the genome with possible switching from the gametophytic way of seed reproduction to the sporophytic one [10].

Apomictic seed reproduction in sugar beet was observed (but not confirmed) in 1928 by M.V. Favorsky. It was confirmed in the 1970s, but considered to be of low importance for breeding, until the work of Levitsky et al., and Maletskii, Maletskaya et al. since the 1990s $[11,12,14]$. Apomictic reproduction of wild Beta species was described by Barocka in 1960 .

It was determined that during apomictic reproduction the meristem cells of sugar beet seedlings demonstrated mixoploidy of cell populations with the presence of both dominating fraction of cells with diploid number of chromosomes and polyploid cells, occurring from the diploid ones by endomitosis [11, 13]. K.I. Maletskaya (2009) proved that apomictic reproduction in pollen sterile lines of beet under pollen free conditions is not somatic cloning and a case of nucellar embryony, and the origin of the embryos in this case is mainly gametophytic reduced and non-reduced parthenogenesis [14]. This basis of embryogenesis under apozygoty 
was also thoroughly studied by Szkutnik (2011) using isoenzyme analysis [7].

Bohomolov (2018) observed gametophytic apomixis in sugar beet as a result of absent meiosis in case of inducing apomixis, while crossing with wild Beta corolliflora L. $(2 n=36)$ and B. trigina L. $(2 n=56)$, when the crossings were exposed to high doses of radiation. Gamma-radiated-lines, forming viable progeny under isolation conditions, were created. This opens the possibility of obtaining 'new generation' hybrids, based on apomictic lines [15].

The method of inducing maternal haploids under in vitro conditions (gynogenesis), using unpollinated seed embryos decreases the period of obtaining homozygous selection materials to $1-2$ years, due to genetic homogeneity of lines of the resulting dihaploids [16, 17]. Zhuzhzhalova et al. (2016) found that an efficient way to stimulate the yield of haploids (from 3.0 to $9.8 \%$ ) was obtained using the liquid basal nutrient medium, based on micro- and macrosalts according to Gamberg et al., to which cytokinin BAP $(1.0 \mathrm{mg} / \mathrm{l})$ was added [17].

Haploid seedlings from apomictic sugar beet seed progenies, formed under pollen free conditions, were first isolated by Maletskaya [14]. The only so far possible method of obtaining haploid and dihaploid lines in vivo is the selection of haploids on the basis of morphology (by measuring thickness and length of the tip on days 2-3 after germination). The yield of haploids is usually not more than $3.79-6.25 \%$, and it includes a long process of ploidy stabilization of both somatic and generative cells [14]. It was proven in the experiments using 150 pollen sterile lines under pollen free conditions in the Laboratory of Cytogenetics, the Institute of Bioenergy Crops and Sugar Beet (Kyiv, Ukraine) that the regenerants from apomictic plants include haploids, diploids and tetraploids, as determined using flow cytometry on total DNA content of interphase nuclei with the Partec Ploidy Analyser PA-II (Partec Company, Germany) [18]. Mixoploid genomes in the apomictic progeny of sugar beet are unstable and change to the diploid level in the course of four cycles of apomictic seed reproduction in micropropagation [19].

The seed of selection materials of sugar beet, obtained via parthenogenesis via polyembryony, is characterized by genetic diversity; the generation of 2-3 shoots from some apocarpous fruit was observed [7, 14,]. Embryological studies demonstrated that apomictic seeds originated both from somatic cells (adventive embryony) and from generative cells of the embryo sac $[11,12]$. Such formations of seeds are called seed cloning, but theoretically this progeny should not be homogeneous, since they are of different genetic nature out of somatic and generative cells. Levites et al. (2016) discovered that polymorphism of enzymes, present in these apomictic plants, was related to relocation of the enzymatic locus and variability of their expression due to difference in the structure of isoenzymes [20].

The variability of ploidy level and the occurrence of partial mixoploidy in apomictic sugar beet plants complicate the selection of valuable breeding features in those plants $[15,19]$. Once the problem of differentiating progeny is solved, somatic and generative apomixis in materials with CMS will allow using the apomictic method of seed reproduction to induce homozygous lines and obtain constant progeny which will improve the sugar beet breeding programs.

The aims of our research were 1) to select generative parthenogenetic seeds and determine ploidy of apomictic embryos; 2) to induce and produce dihaploid lines under in vitro conditions depending on the genotype and plasmotype of seed plants-donors of sugar beet using cytophotometry methods of determining ploidy and selection of haploid and diploid regenerants in vitro from the embryo culture of apomictic embryos; 3 ) to study the specificities of regenerating apomictic embryos in alloplasmic lines and lines with new sterile cytoplasm from wild Beta maritima and Beta patula.

The following experiments were conducted to achieve the above-mentioned aims:

- the effect of hormonal composition of the basal culture medium according to Gamberg et al. (1968) [21], taking the genotype of seed plants-donors into account, on differentiation processes in the culture of apomictic embryos;

- the differentiation of apomixis type (analysis of variability of the ploidy level of the genome in second generation regenerants) by determining the total content of nuclear DNA of interphase nuclei using fluorescent flow cytometry;

- subsequent isolation of homozygous lines in micropropagation based on differentiation and in vitro selection of haploids and dihaploids, obtained without the effect of colchicine.

\section{MATERIALS AND METHODS}

The initial material for the study on the specificities of inducing the embryo culture, obtaining regenerants 
based on apozygoty and CMS was seed plants of pollen sterile apocarpous lines of sugar beet of Yaltushkivska experimental breeding station with $B$. vulgaris Owen cytoplasm (1945) and alloplasmic lines with new sources of cytoplasmic sterility from wild species of Beta L. - Beta maritima, from natural populations of Greece and Turkey, and Beta patula of Madeira, Portugal).

The following seed plants were used as donors of apomictic embryos in our research:

- apomictic lines of seed plants $\mathrm{A}_{4-7}$ with selection numbers $13-1365,12$; 13-138 p.1, 5, 8 were formed under conditions of the greenhouse breeding complex of Yaltushkivska EBS. At least 10 out of 100-150 seed donors from each line were selected by the features of separate flowers (mm) and of sterility (MS-0) [22]. For seed plants of each apomictic line, about 2,000 flowers were analyzed after the start of flowering, within the development period from day 12 to day 32 ;

- alloplasmic pollen sterile lines based on new male sterile cytoplasm from wild Beta maritima and Beta patula, with high apomictic seed production with the following selection numbers: $\mathrm{B}_{4} \mathrm{CS}$ patula $\mathrm{A}_{2}: 18$ (Madeira, Portugal) p.1, p.2, p.3, ${ }_{6} C S$ patula $\mathrm{A}_{2}: 18$ p.2, p.5) $\mathrm{B}_{3} \mathrm{CS}$ maritima (Turkey) $\mathrm{A}_{1:} 18, \mathrm{p} .1, \mathrm{p} .2, \mathrm{p} .5 \mathrm{~B}_{3} \mathrm{CS}$ maritima (Greece) $\mathrm{A}_{2}: 18$ p.1, p.2.

The alloplasmic lines were created in the Laboratory of Cytogenetics as reciprocal progeny of wild species of Beta maritima and Beta patula of the above-mentioned different ecologic-geographic origin [23]. New sterile cytoplasm was selected from crossings with the wild beet species by determining the recessive nuclear genes of sterility fixation: hypocotyl coloring r-r-, two-year cycle of development b-b-, apocarpous nature $\mathrm{mm}$, sterility xxzz.

Pollen free conditions with the purpose of inducing apomictic seeds were ensured by spatial isolation of seed plants under conditions of the greenhouse breeding complex of the Yaltushkivska breeding station, as well as application of parchment isolators on the experimental field of the Institute of Bioenergy Crops and Sugar Beet [22]. Pollen free mode comprised cultivating MS-0 sugar beet plants on isolated plots in the greenhouse breeding complex. In August, the seeds of MS-lines were grown in a cycle (from seed to seed). The phenotype of each plant was determined by pollen features prior to flower opening. The plants with completely sterile pollen MS-0 phenotype according to Owen (1945) were kept for reproduction. Parchment isolators were put on specific shoots of seed plants to safeguard apozygous reproduction. During the flowering in the following May-June the temperature fluctuated from $38{ }^{\circ} \mathrm{C}$ to $51{ }^{\circ} \mathrm{C}$. Seed plants of MS-0 type were selected for the pollen free reproduction method and MS-I and MS-II types were discarded [18].

\section{The evaluation of embryogenesis of apomictic embryos}

Among seed plants of sugar beet, the ones with the best development of seed plant habitus, forming apocarpous pollen-sterile microspecies (biotypes) in terms of development of generative shoots were selected to be donors of embryos.

The distinguishing and marking of flowers on breeding materials of pollen sterile lines, obtained in pollen free mode, was performed by the modified method of Shyriaeva of 1984, [24]. This method envisages distinguishing the buds, which have opened, and marking them with color threads up and below. The marking of male sterile flowers was conducted from 8.00 a.m. till 11 a.m. depending on the temperature.

For microscopic observation apomictic embryos were fixed in Carnoy's fixative (3 volumes of ethyl alcohol : 1 volume of glacial acetic acid) for 14 days at $+4{ }^{\circ} \mathrm{C}$. After the fixation, the material was washed and desiccated three times in $75 \%$ ethyl alcohol for $1 \mathrm{~h}$. The washed material was kept in $80 \%$ ethyl alcohol for preparations. Thin sections were made by hand using a sharp razor blade. The sections were placed on the specimen slide one after another and stained for $2 \mathrm{~h}$ in the solution of glycerin with the addition of $9 \%$ alcoholic iodine solution. After washing in running water for $12 \mathrm{~h}$, the sections were placed in a glycerin-iodine solution and mounted under a coverslip on a microscope slide. The preparations were studied under the stereoscopic microscope (LOMO MBS-10). The developmental stage of embryos was determined on the fifth day after flowering when the embryo was at the globular stage, the heart stage was observed on day 8 , and on days 10-12 the torpedo and «cotyledon = root» stage (where the cotyledon and hypocotyl were getting longer). On day 16 the embryo reached the $\left\langle\left\langle^{1} / 2\right\rangle\right.$ stage of the embryo sac, and on day $20-22-\langle 3 / 4 »$ of the embryo sac. On day 24 the embryo developed up to the chalazal end of the sprout and completed its development on day 28 under the conditions of pollination, fertilization and formation of hybrid embryos. We observed the location of the embryo sac of sugar beet in the micropylar part of the seed embryo, the embryo developed from the micropylar to the chalazal end. A light microscope 


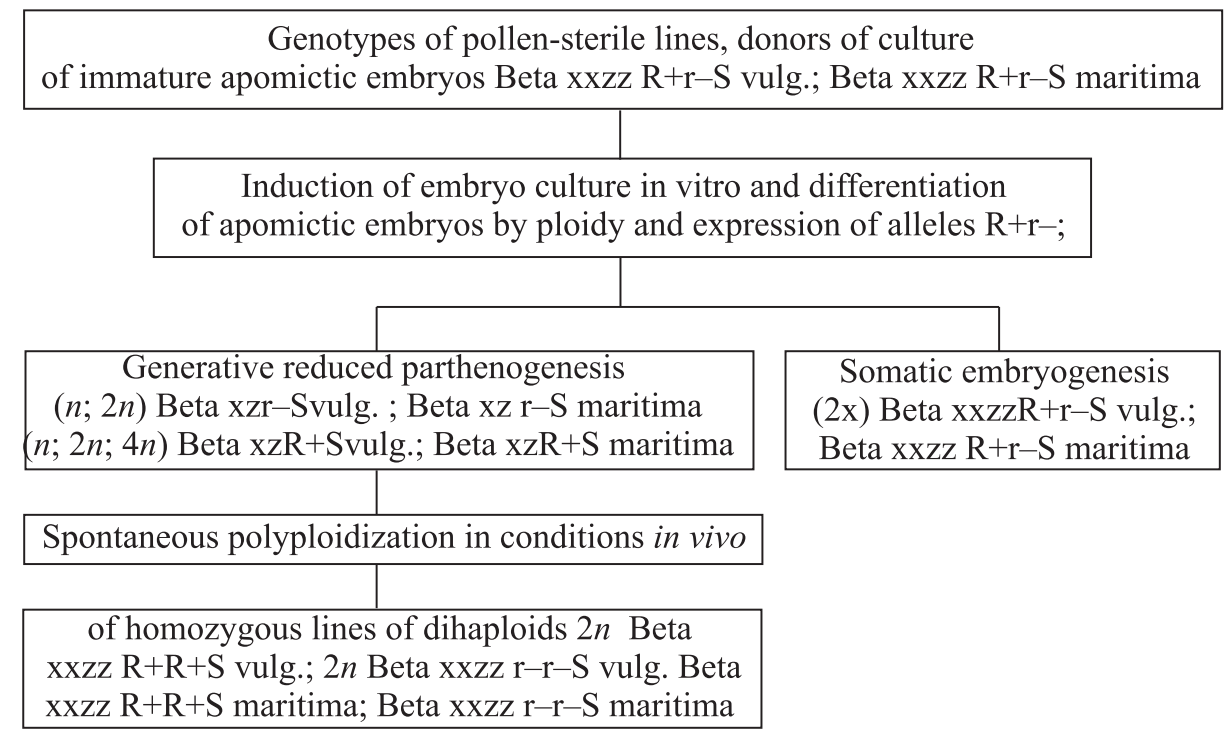

Fig. 1. Genetic method of inducing haploids and dihaploids in the culture of apomictic embryos

MBS-10 (LOMO, Russia) was used for cytological analysis while magnifying objects $12.5 \times 7$. Microphotography was conducted using a Sigeta digital camera in combination with the computer program ToupView (Touptek Photonics, China), applying Twain and Direct Show software.

The method of obtaining a culture of embryos from selected materials of sugar beet possessing cytoplasmatic male sterility and apomixis

To optimally induce the culture of apomictic embryos, different compositions of nutrient media were investigated, using different ratios of cytokines, auxins, carbohydrates and amino acids, based on a macro- and microsalts medium of Gamberg et al. (1968) [21]. The duration of the development of apomictic embryos was calculated from the start of flowering of seed plants.

Medium No. 212, previously developed at the Institute of Bioenergy Crops and Sugar Beet [25] to induce haploids from immature seed embryos and based on micro- and macrosalts according to Gamberg et al. [21], was used as control, to adjust the composition of the media with the purpose of inducing embryo culture during apozygoty. Due to delay in the development of embryos from apomictic lines, we changed the period of selecting breeding material for further use to 10 days. To induce the embryo culture in vitro, we used stress conditions in a combination of low $\left(+4{ }^{\circ} \mathrm{C}\right)$ and high $\left(+33{ }^{\circ} \mathrm{C}\right)$ temperatures. The excised ovules were sterilized in a solution of $20 \%$ chloramine and subsequently kept at $+4{ }^{\circ} \mathrm{C}$ in the refrigerator for 2 days with the illumination of $3 \mathrm{klx}, 16 \mathrm{~h}$ photoperiod, and a relative humidity of at least $75 \%$. Then they were transferred onto medium No. 3 of Gamberg et al. (1968) [21] and kept in a thermostat at $+33{ }^{\circ} \mathrm{C}$ for 30 days with the illumination of 8-10 klx, $16 \mathrm{~h}$ photoperiod, a relative humidity of at least $80 \%$, and $\mathrm{CO}_{2}$ at $0.1-0.12 \%$. Subsequently, to activate plant growth, the embryo structures formed in the 30 days before, were transferred to the medium according to Gamberg et al. (1968) with the addition of $0.3 \mathrm{mg} / \mathrm{l} \mathrm{BAP}$ and gibberellin $1 \mathrm{mg} / 1$ for microclonal reproduction. The genetic method of inducing haploids and dihaploids in sugar beet with apomixis and CMS to obtain homozygous lines (Fig. 1), was applied when differentiating regenerative plants of the second passage [26]. The roots of seed plantsdonors of apomictic embryos of pollen-sterile lines and alloplasmic lines were differentiated on the basis of the allele of marker red color of hypocotyl $\mathrm{R}+$. The differentiation of haploids, mixoploids and dihaploids was conducted on regenerant plants of the second passage using hypocotyl marker color $(\mathrm{R}+; \mathrm{r}-)$ and by determining ploidy using fluorescent cytophotometric analysis by the Partec Ploidy Analyser PA-II and its computer programs (Partec company, Germany).

The genetic method of inducing haploid and dihaploid lines based on the embryo culture of apomictic embryos of sugar beet is presented in Fig. 1.

The regenerants of passage II of each genotype were separately analyzed both by marker coloring of the hypocotyl $(\mathrm{R}+\mathrm{r}-)$, and by the level of genome ploidy using fluorescent flow cytometry and computer programs of the Partec Ploidy Analyser PA-II.DNA of peas (Pisum sativum) as well as nuclei of cells of animals and hu- 
mans served as reference. When ploidy was determined by the flow cytometry, leaves of control specimen with previously determined number of chromosomes for this species were used. We used the leaves of haploid and diploid biotechnological lines with the number of chromosomes determined as external standard for sugar beet. The objects of analyzing the shoots in vitro were their leaves, containing cells of different tissues after preparing the suspension according to the method of Partec company.

It was proven that the main bulk of cells of sugar beet leaves was at the $\mathrm{G}_{0}$ stage, representative for interphase nuclei in the pre-synthetic period and corresponding to ploidy in general [27]. We detached leaves during replanting of regenerated shoots in a laminar flow cabinet and kept them in bags with moistened filtration paper in the refrigerator at $+4{ }^{\circ} \mathrm{C}$. To prepare the suspension of nuclei, a part of a leaf was cut with a sharp razor in Petri dishes with the addition of $1.5 \mathrm{ml}$ extraction (lysing) buffer solution (Partec, Germany). The buffer solution included $10 \mathrm{mM}$ - aminomethane; $10 \mathrm{mM} \mathrm{Na} 2$ EDTA; $100 \mathrm{mM}$ - NaCl; pH 7.7; $100 \mathrm{ml}$ - mo-ther solution DAPI (Germany). After cutting we added $0.5 \mathrm{ml}$ of DAPI fluorochrome solution (Partec, Germany) and 0.5 $\mathrm{ml}$ propidium iodide (4,6-diamidino-2-phenylindole). Histograms were generated that describe the distribution of the investigated cellular DNA, and the number of cells with a particular content of nuclear DNA. The number of measurements was from 2 to 150 thousand nuclei per sample. Diploid level of the genome corresponds to the peak on the channel 100 and the class of cells with double content of nuclear DNA - on the channel 200 (Fig. $5, c)$. The number of samples from each apomictic line corresponded to the number of regenerated apomictic embryos.

The leaves of regenerated in vitro shoots were used to determine ploidy. The obtained plants were stabilized by ploidy to the diploid level during 3-4 passages, and after a check using PA Partec and the stabilization followed by their microclonal reproduction in vitro. The basal medium of Gamberg et al. (1968), with the addition of $0.1 \mathrm{mg} / 1$ naphthyl acetyl and $0.3 \mathrm{mg} / \mathrm{l}$ indole butyric acids, $0.5 \mathrm{mg} / 1$ gibberellin, $45 \mathrm{mg} / 1$ sucrose, $\mathrm{pH}$ 5.6, 5.8, was used for rooting. After rooting, plantlets were selected for further cultivation on the basis of morphological features and high regeneration percentage of root system and leaf apparatus.

\section{Rooted clones}

The rooted clones were transferred into growth medium under conditions of the greenhouse breeding complex of Yaltushkivska experimental breeding station. The growth medium was prepared prior to planting (40\% soil, $30 \%$ humus and $30 \%$ sand) and placed into pots, $35 \mathrm{~cm}$ in diameter. Mineral fertilizers were introduced as calculated per $60 \mathrm{~kg}$ of growth medium - ammonium nitrate (34 \%) - 40-50 g, superphosphate $(19 \%)-100-110 \mathrm{~g}$, potassium salt $(40 \%)-30$ $40 \mathrm{~g}$. The survival of young plants in pots was from 99 to $100 \%$. The humidity of $60-70 \%$ from total moisture capacity was preserved with a relative humidity of $75 \%$.

During the vegetation of plants, the air temperature in the greenhouse fluctuated from $35{ }^{\circ} \mathrm{C}$ to $55{ }^{\circ} \mathrm{C}$ in April-May, with the illumination of 10-12 klx.

To determine the reliability of the analysis and sampling accuracy, the coverage error $m p$ [28] was determined by the formula:

$$
m p= \pm \sqrt{\frac{P(100-P)}{n},}
$$

where $P$ - the percentage of regenerants from the embryo culture grown in vitro, determined by the type of morphogenesis depending on hormonal composition of cultural media, or by the ploidy level of the genome using cytophotometric methods; $n$ - number of seed embryos from one apomictic line.

\section{RESULTS}

In the apomictic line $\left(A_{6}\right)$ 13-138 p.1, there was considerable degeneration of seed embryos under pollen free conditions, which could exceed $80 \%$ (Table $1)$, the development of apomictic embryos on day 12 reached the globular stage (Fig. 2,a), and that was 4 days behind the hybrid one according to the scheme of development for hybrid embryos, determined for Beta vulgaris [24], that reached the torpedo stage already. In the alloplasmic line $\mathrm{B}_{3} \mathrm{CS}$ maritima (Turkey) $\mathrm{A}_{2}: 18$ p.5 the development of apomictic embryos was observed at the heart stage on day 20 which was 12 days behind the hybrid one.

On day 12 we observed the development of apomictic embryos at the globular stage, and on day 20-22 at the heart stage, torpedo stage, $\langle 1 / 2\rangle$ of the embryo sac, and the cotyledon $=$ root or $\mathrm{c}=\mathrm{r}$ stage, depending on the genotype of seed plants-donors (Fig. 2, $a-d$ ).

At $+33{ }^{\circ} \mathrm{C}$ the isolated embryos formed leaves, roots and/or callus depending on the composition of cultural media and origin of the material. Four variants of the basal medium with different amounts and ratio of cytokines, auxins, and saccharose were analyzed. The basal cultural medium which was previously developed 
to obtain haploid plants from isolated non-fertilized seed embryos by Bilous et al, [25], was used as control. The differentiating characteristics of regenerants, depending on their genotype and composition of cultural media under in vivo conditions are presented in Table 1.

According to Table 1, medium No. 3 yielded the highest number of regenerants for four different lines in one experiment. The yield of differentiating callus depended on genotype of the tested lines and fluctuated from 6 to $10.0 \%$. Direct embryogenesis was observed in all the control genotypes, Table 1 also presents the total number of seed embryos. The indices of direct regeneration are indices of the number of regenerated apomictic embryos for each control line (see Fig. 3, a),

Table 1. The types of morphogenesis in culture of apomictic embryos in two lines with cytoplasmatic male sterility (CMS) of sugar beet and two alloplasmic lines, depending on their genotype and three variations in composition of the basal cultural medium according to Gamberg et al., 1968 (24), and with medium 212 of Bilous et al. 2006 (25) as control

\begin{tabular}{|c|c|c|c|c|c|c|c|c|}
\hline \multirow{3}{*}{$\begin{array}{c}\text { Types of } \\
\text { morphogenesis }\end{array}$} & \multicolumn{8}{|c|}{ Experimental number and genetic make-up of cell line } \\
\hline & \multicolumn{2}{|c|}{$\begin{array}{l}\text { 13-136 A }: 18 \text { p.5 } \\
\text { CMS line }\end{array}$} & \multicolumn{2}{|c|}{$\begin{array}{c}\text { 13-138 A : }: 18 \text { p.5 } \\
\text { CMS line }\end{array}$} & \multicolumn{2}{|c|}{$\begin{array}{l}\mathrm{B}_{3} \mathrm{CS} \text { maritima } \\
\text { «Ts» A2:18 p.5 } \\
\text { Alloplasmic line }\end{array}$} & \multicolumn{2}{|c|}{$\begin{array}{c}\text { B }_{6} \text { CS patula A2:18 p. } 2 \\
\text { Alloplasmic line }\end{array}$} \\
\hline & $* \mathrm{R}$ & $\%$ & $\mathrm{R}$ & $\%$ & $\mathrm{R}$ & $\%$ & $\mathrm{R}$ & $\%$ \\
\hline
\end{tabular}

Control medium No. 212 [25] Organic additives**** Gibberellic acid $0.1 \mathrm{mg} / \mathrm{l}$; Phytohormones: 6 BAP - 0.5 mg/l, 2.4 D $0.1 \mathrm{mg} / \mathrm{l}$ Carbohydrate: saccharose $30 \mathrm{~g}$ glucose $20 \mathrm{~g}$ Adenine $2 \mathrm{mg} / \mathrm{l}$

\begin{tabular}{l|c|c|c|c|c|c|c|c}
\hline undifferentiated callus & 3 & $2.68 \pm$ & 7 & $3.25 \pm 1.21$ & 11 & $10.48 \pm$ & 4 & $2.28 \pm 1.13$ \\
direct embryogene-sis & 5 & $1.52 \#$ & 4 & $1.86 \pm 0.92$ & 7 & 2.98 & 6 & $3.43 \pm 1.38$ \\
differentiating callus & 10 & $4.46 \pm 1.95$ & 3 & $1.39 \pm 0.79$ & 1 & $6.67 \pm 2.43$ & 5 & $2.86 \pm 1.25$ \\
Total:*** & 112 & $8.93 \pm 2.69$ & 215 & c. 5.5 & 105 & $0.95 \pm 0.21$ & 175 & c. $7.4 \%$ \\
& (94 lost) & c. $16 \%$ & (201 lost) & & (86 lost) & c. $18 \%$ & (160 lost) & \\
\hline
\end{tabular}

Macro- and microelements see [24] Organic additives**** Gibberellic acid 0.1 mg/l Phytohormones: 6 BAP - 0.4 mg/l, $\mathrm{NAA}^{* *}{ }_{-} 0.1 \mathrm{mg} / \mathrm{l}, 2.4 \mathrm{D} 0.1 \mathrm{mg} / \mathrm{l}$ Carbohydrate: saccharose $30 \mathrm{~g}$

\begin{tabular}{l|c|c|c|c|c|c|c|c}
\hline undifferentiated callus & 3 & $3.0 \pm 1.7$ & 2 & $0.99 \pm 0.69$ & 4 & $3.81 \pm 1.87$ & 1 & $0.89 \pm 0.7$ \\
direct embryogene-sis & 7 & $7.0 \pm 2.5$ & 6 & $2.98 \pm 1.19$ & 9 & $8.57 \pm 2.73$ & 5 & $4.46 \pm 1.95$ \\
differentiating callus & - & - & - & - & - & - & - & - \\
Total:*** & 100 & c. $10 \%$ & 201 & c. $4 \%$ & 105 & c. $12.2 \%$ & 112 & \\
& $(90$ lost $)$ & & & & & & & \\
\hline
\end{tabular}

Macro- and microelements see [24] Organic additives**** Gibberellic acid 0.1 mg/l Phytohormones: 6 BAP - 2 mg/l, $2.4 \mathrm{D}-0.5 \mathrm{mg} / \mathrm{l}$ Carbohydrates: saccharose $30 \mathrm{~g}$, glucose $10 \mathrm{~g}$

\begin{tabular}{l|c|c|c|c|c|c|c|c}
\hline undifferentiated callus & 4 & $1.60 \pm 0.79$ & - & - & - & - & - & - \\
direct embryogene-sis & 25 & $10.0 \pm 1.89$ & 11 & $4.40 \pm 1.29$ & 35 & $23.3 \pm 3.45$ & 27 & $18.0 \pm 3.14$ \\
differentiating callus & 20 & $8.0 \pm 1.72$ & 15 & $6.0 \pm 1.5$ & 14 & $9.33 \pm 2.37$ & 15 & $10.0 \pm 2.45$ \\
Total:*** & 250 & c. $19 \%$ & 250 & c. $10.4 \%$ & 150 & c. $32 \%$ & 150 & c. $28 \%$ \\
& $(201$ lost $)$ & & & & & & & \\
\hline
\end{tabular}

Macro- and microelements see [24] Organic additives**** Gibberellic acid 0.1 mg/l Phytohormones: 6 BAP - 4 mg/l, $2.4 \mathrm{D}-1 \mathrm{mg} / \mathrm{l}$ Carbohydrates: saccharose $30 \mathrm{~g}$

\begin{tabular}{l|c|c|c|c|c|c|c|c}
\hline undifferentiated callus & 16 & $16.0 \pm 3.7$ & 4 & $2.67 \pm 1.32$ & 7 & $4.67 \pm 1.72$ & 11 & $11.0 \pm 3.12$ \\
direct embryogene-sis & - & - & - & - & - & - & - & - \\
differentiating callus & 3 & $3.0 \pm 1.71$ & 2 & $1.33 \pm 0.7$ & 2 & $1.33 \pm 0.93$ & - & - \\
Total:*** & 100 & c. $21 \%$ & 150 & c. $4 \%$ & 150 & c. $6 \%$ & 100 & c. $11 \%$ \\
& $(81$ lost $)$ & & & & & & & \\
\hline
\end{tabular}

Note: $\#=$ standard deviation $* \mathrm{R}$ - number of regenerants by morphogenesis type; **NAA - naphthyl acetic acid; ***Total number of induced seed embryos at late stages of embryogenesis; **** Organic additives: nicotinic acid $0.5 \mathrm{mg} / 1$; pyridoxine $0.1 \mathrm{mg} / 1$; glycine $3 \mathrm{mg} / \mathrm{l}$; glutamine $1 \mathrm{mg} / \mathrm{l}$; thiamine $0.1 \mathrm{mg} / 1$; $\beta$-alanine $1 \mathrm{mg} / \mathrm{l}$; ascorbic acid $3 \mathrm{mg} / \mathrm{l}$; meso-inositol $100 \mathrm{mg} / \mathrm{l}$. 

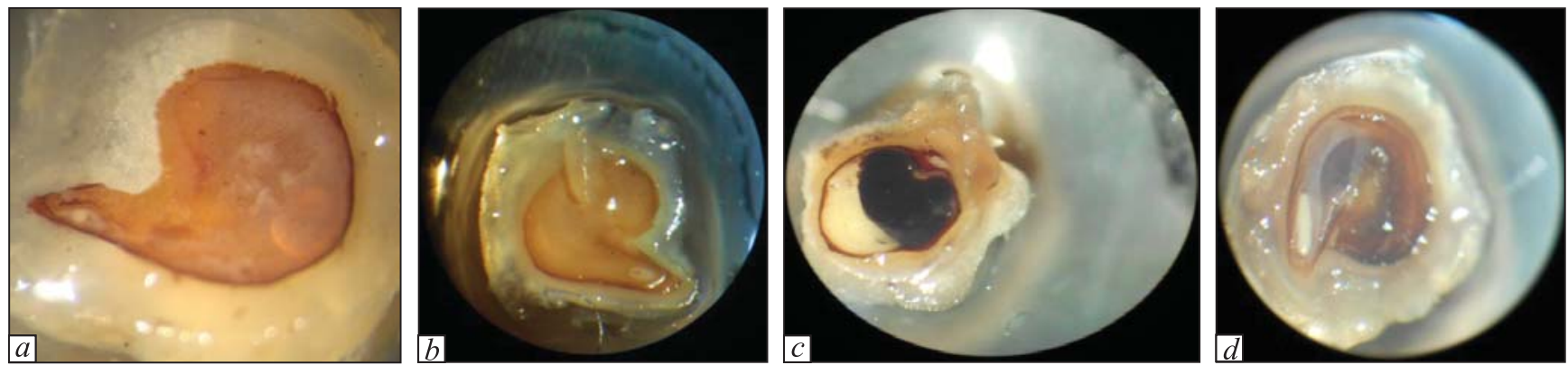

Fig. 2. Developmental stages of apomictic embryos, potential material for embryo culture: $a$ - embryo at the globular stage of sugar beet line $\left(\mathrm{A}_{6}\right)$ 13-138 p.1 on day $12 ; b$ - heart stage in alloplasmic line $\mathrm{B}_{3} \mathrm{CS}$ maritima (Turkey) $\mathrm{A}_{2}: 18$ p.5 on day $20 ; c$ - degeneration of one embryo and development at the «cotyledon = root» stage in case of polyembryony in alloplasmic $\mathrm{B}_{6} \mathrm{CS}$ patula p.2 $\mathrm{A}_{2}: 18 ; d$-torpedo stage in sugar beet line $13-136$ p.5 on day 22
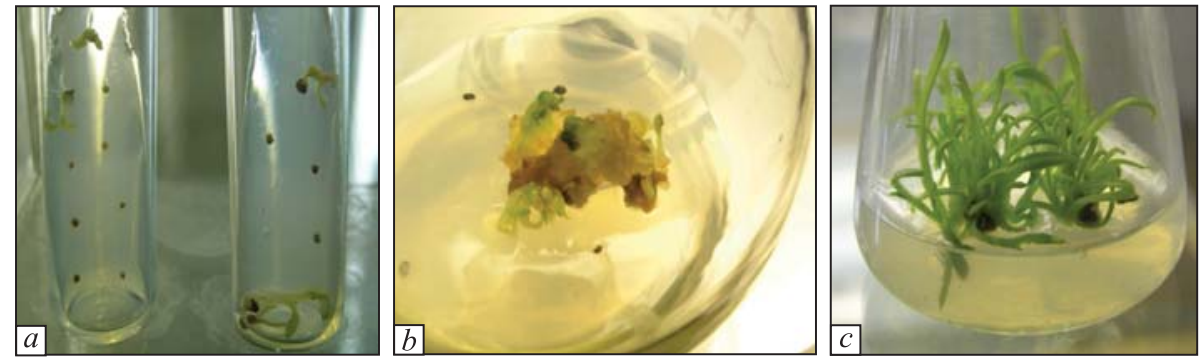

Fig. 3. The induction of alloplasmic and CMS embryo culture: $a$ - direct regeneration of shoots in the culture of apomictic embryos in alloplasmic line $\mathrm{B}_{6} \mathrm{CS}$ patula, $\mathrm{A}_{2}: 18$ p. $2 ; b$ - tissue differentiation and organogenesis in alloplasmic line $\mathrm{B}_{3} \mathrm{CS}$ maritima «Ts» $\mathrm{A}_{2}: 18$ p.5; $c$ - development of shoots from the differentiating callus in the culture of embryos in haploid CMS line $13-138 \mathrm{~A}_{6}: 18$ p.5
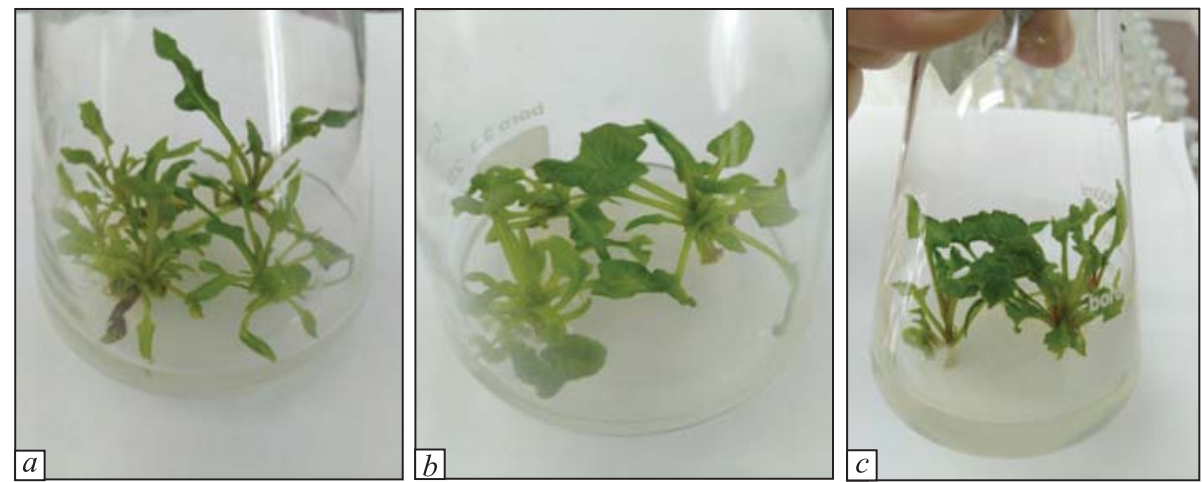

Fig. 4. Shape of leaves and expression of dominant allele $\mathrm{R}+$ and recessive allele $\mathrm{r}$ - in regenerants of apomictic embryos: $a-$ the expression of allele $\mathrm{r}$ - in the haploid line 13-138 $\mathrm{A}_{6}: 18 \mathrm{p} .1$ showing the absence of red color in vitro by the expression of allele $\mathrm{r}-; b$ - recessive homozygote, showing silencing of the gene responsible for anthocyanin formation in the hypocotyls in line $\mathrm{B} 3 \mathrm{CS} ; c$ - presence of a dominant allele $\mathrm{R}+$ in line $B_{6}$ CS patula $\mathrm{A}_{2}: 18$ p.5, anthocyanin formation in hypocotyl

but it depended on the genotype and on the plasma type of seed plants-donors. It fluctuated from 4.4 to $10.0 \%$ for two selection numbers of apomictic, apocarpous pollen free lines of $B$. vulgaris. Direct regeneration at the heart stage, and $\ll \mathrm{c}=\mathrm{r} »$ stage was substantial for the alloplasmic lines $\mathrm{B}_{3} \mathrm{CS}$ maritima «Ts» $\mathrm{A}_{2}: 18$ p.5 and $B_{6} C S$ patula $\mathrm{A}_{2}: 18$ p. 2 . The characteristics of induced morphogenetic processes in alloplasmic and CMS embryo culture via direct regeneration are presented in Fig. 3.
Generally, a dose of the cytokinin BAP at $0.3 \mathrm{mg} / 1$ and gibberellin at $1 \mathrm{mg} / \mathrm{l}$ resulted in growth stimulation and development of beet explants, obtained via direct regeneration, in the course of two passages in micropropagation. The obtained regenerants were planted onto the medium to stimulate growth only. Practically all the variants of investigated media demonstrated positive effect on growth by the hormones applied in our experiment in four different doses. The number of 
side shoots was from 4 to 8 per explant, and that of morphologically developed shoots $-75-100 \%$. The medium with cytokinin BAP $0.3 \mathrm{mg} / 1$ and $1 \mathrm{mg} / 1$ gibberellin was selected and used as the medium most suitable to regenerate and micropropagate plants. On this medium clone, formed during the second passage, were characterized by intense green leaves, normal ratio of a top and a leaf, and active regeneration of next passage clones. The increase in the concentration of each hormone from 0.5 to $1 \mathrm{mg} / 1$ resulted in tissue necrosis in explants. When the duration of cultivation was prolonged, first and second passage regenerant plants showed toxic effects of phytohormones and the forma- tion of plants with modified morphology - a modified form of a leaf blade and the ability of active regeneration of shoots.

Variability in morphology of the leaf blade, even within one selection number, was observed in second passage plantlets.

This variability in the shape of leaves and the expression of dominant allele $\mathrm{R}+$ and recessive allele $\mathrm{r}$ - in the regenerants of different ploidy is presented in Fig. 4.

According to the genetic expectations based on the occurrence of haploids and dihaploids in the culture of apomictic sugar beet embryos, and described earlier

Table 2. The variability of ploidy of embryonic regenerants of apomictic (CMS and alloplasmic) sugar beet lines (all of the $\mathrm{R}+\mathrm{r}-$ anthocyanin hypocotyl coloring genotype), as measured by the quantity of total DNA in their interphase nuclei

\begin{tabular}{|c|c|c|c|c|c|c|c|c|c|c|}
\hline \multirow{3}{*}{$\begin{array}{l}\text { Selec- } \\
\text { tion } \\
\text { number, } \\
\text { apomic- } \\
\text { tic lines }\end{array}$} & \multirow{3}{*}{$\begin{array}{c}\text { Period } \\
\text { of embry- } \\
\text { onic } \\
\text { deve- } \\
\text { lopment, } \\
\text { days }\end{array}$} & \multirow{3}{*}{$\begin{array}{l}\text { Genotype } \\
\text { of donor } \\
\text { plants by } \\
\text { the ex- } \\
\text { pression } \\
\text { of alleles } \\
\mathrm{R}+\mathrm{r}\end{array}$} & \multirow{3}{*}{$\begin{array}{l}\text { Number } \\
\text { of } \\
\text { planted } \\
\text { seed } \\
\text { embryos }\end{array}$} & \multirow{3}{*}{$\begin{array}{c}\text { Rege- } \\
\text { nerated } \\
\text { embryos, } \\
\%\end{array}$} & \multicolumn{6}{|c|}{$\begin{array}{l}\text { Ploidy on the basis of total DNA in interphase nuclei, } \\
\text { depending on the number of embryos obtained (\%) }\end{array}$} \\
\hline & & & & & \multicolumn{3}{|c|}{ green, $\mathrm{r}-$} & \multicolumn{3}{|c|}{ red, $\mathrm{R}+$} \\
\hline & & & & & $n$ & $n, 2 \mathrm{x}$ & $\begin{array}{c}n, 2 n \\
4 n\end{array}$ & $\begin{array}{c}n, 2 n \\
4 n\end{array}$ & $2 \mathrm{x}$ & $\begin{array}{c}2 n, 4 n \\
8 n\end{array}$ \\
\hline \multicolumn{11}{|c|}{$\mathrm{B}_{3} \mathrm{CS}$ maritima (Greece) $\mathrm{A}_{2}: 18$} \\
\hline p. $1^{*}$ & 22 & $\begin{array}{l}\mathrm{R}+\mathrm{r}- \\
\mathrm{R}+\mathrm{r}-\mathrm{r}\end{array}$ & 210 & $23.3 \pm 2.3 \#$ & $14(6.7)$ & - & $13(6.2)$ & $4(1.9)$ & $18(8.6)$ & - \\
\hline \multicolumn{11}{|c|}{$\mathrm{B}_{4} \mathrm{CS}$ patula (Madeira) $\mathrm{A}_{2}: 18$} \\
\hline $\begin{array}{l}\text { p. } 1 \\
\text { p. } 2 \\
\text { p. } 3 \\
\end{array}$ & $\begin{array}{l}12 \\
22 \\
32 \\
\end{array}$ & $\begin{array}{l}\mathrm{R}+\mathrm{r}- \\
\mathrm{R}+\mathrm{r}- \\
\mathrm{R}+\mathrm{r}- \\
\end{array}$ & $\begin{array}{c}250 \\
75 \\
84 \\
\end{array}$ & $\begin{array}{c}34.8 \pm 3.02 \\
16.0 \pm 4.2 \\
67.9 \pm 5.1 \\
\end{array}$ & $\begin{array}{c}14(5.6) \\
6(8.0) \\
12(14.3) \\
\end{array}$ & $\begin{array}{l}- \\
- \\
- \\
\end{array}$ & $\begin{aligned} & 28(11.2) \\
& 1(1.3) \\
& 22(26.2) \\
&\end{aligned}$ & $\begin{array}{c}20(8.0) \\
5(6.7) \\
18(21.4) \\
\end{array}$ & $\begin{array}{c}25(10.0) \\
- \\
27(32.1) \\
\end{array}$ & $\begin{array}{c}- \\
- \\
5(6.0) \\
\end{array}$ \\
\hline \multicolumn{11}{|c|}{$\mathrm{B}_{3} \mathrm{CS}$ maritima (Turkey) $\mathrm{A}_{1}: 18$} \\
\hline $\begin{array}{l}\text { p. } 1 \\
\text { p. } 2 \\
\text { p. } 3 \\
\end{array}$ & $\begin{array}{l}12 \\
22 \\
32 \\
\end{array}$ & $\begin{array}{l}\mathrm{R}+\mathrm{r}- \\
\mathrm{R}+\mathrm{r}- \\
\mathrm{R}+\mathrm{r}-\end{array}$ & $\begin{array}{l}250 \\
171 \\
150 \\
\end{array}$ & $\begin{array}{c}4.0 \pm 1.2 \\
45.0 \pm 3.8 \\
46.0 \pm 4.1\end{array}$ & $\begin{array}{c}15(6.0) \\
14(8.2) \\
9(6.0) \\
\end{array}$ & $\begin{array}{l}- \\
- \\
-\end{array}$ & $\begin{array}{l}45(18.0) \\
22(12.9) \\
25(16.7)\end{array}$ & $\begin{array}{c}10(4.0) \\
- \\
9(6.0)\end{array}$ & \begin{tabular}{|c|}
$17(6.8)$ \\
$29(17.0)$ \\
$26(17.3)$ \\
\end{tabular} & $\begin{array}{c}13(5.2) \\
12(7.0) \\
- \\
\end{array}$ \\
\hline \multicolumn{11}{|c|}{$\mathrm{B}_{6} \mathrm{CS}$ patula (Madeira) $\mathrm{A}_{2}: 18$} \\
\hline $\begin{array}{l}\text { p. } 2 \\
\text { p. } 5 \\
\end{array}$ & $\begin{array}{l}12 \\
22 \\
\end{array}$ & $\begin{array}{l}\mathrm{R}+\mathrm{r}- \\
\mathrm{R}+\mathrm{r}-\end{array}$ & $\begin{array}{l}175 \\
112 \\
\end{array}$ & $\begin{array}{c}8.6 \pm 2.6 \\
23.0 \pm 4.0 \\
\end{array}$ & $\begin{array}{l}- \\
- \\
\end{array}$ & $\begin{array}{l}- \\
- \\
\end{array}$ & $\begin{array}{c}5(2.9) \\
18(16.1) \\
\end{array}$ & $\begin{array}{c}5(2.9) \\
- \\
\end{array}$ & $\begin{array}{l}- \\
- \\
\end{array}$ & $\begin{array}{l}5(2.9) \\
8(7.1) \\
\end{array}$ \\
\hline \multicolumn{11}{|c|}{$13-138 \mathrm{~A}_{6}: 18$} \\
\hline $\begin{array}{l}\text { p. } 1 \\
\text { p. } 5 \\
\text { p. } 8 \\
\end{array}$ & $\begin{array}{l}22 \\
22 \\
22 \\
\end{array}$ & $\begin{array}{l}\mathrm{R}+\mathrm{r}- \\
\mathrm{R}+\mathrm{r}- \\
\mathrm{R}+\mathrm{r}-\end{array}$ & $\begin{array}{l}112 \\
215 \\
150 \\
\end{array}$ & $\begin{array}{c}16.1 \pm 3.5 \\
8.8 \pm 1.9 \\
10.0 \pm 2.5\end{array}$ & $\begin{array}{l}2(1.8) \\
8(3.7) \\
3(2.0) \\
\end{array}$ & $\begin{array}{l}- \\
- \\
- \\
\end{array}$ & $\begin{array}{c}- \\
11(5.1) \\
12(8.0) \\
\end{array}$ & $\begin{array}{l}- \\
- \\
- \\
\end{array}$ & $\begin{array}{c}8(7.1) \\
- \\
- \\
\end{array}$ & $\begin{array}{c}8(7.1) \\
- \\
- \\
\end{array}$ \\
\hline \multicolumn{11}{|c|}{$13-136 \mathrm{~A}_{6}: 18$} \\
\hline $\begin{array}{l}\text { p. } 5 \\
\text { p. } 12\end{array}$ & $\begin{array}{l}22 \\
22\end{array}$ & $\begin{array}{l}\mathrm{R}+\mathrm{r}- \\
\mathrm{R}+\mathrm{r}-\end{array}$ & $\begin{array}{l}105 \\
100\end{array}$ & $\begin{array}{l}13.3 \pm 3.5 \\
12.0 \pm 3.2\end{array}$ & $\begin{array}{l}7(6.7) \\
2(2.0)\end{array}$ & $\begin{array}{l}- \\
-\end{array}$ & $\begin{array}{l}7(6.7) \\
5(5.0)\end{array}$ & $\begin{array}{l}- \\
-\end{array}$ & $\begin{array}{l}- \\
-\end{array}$ & $\begin{array}{c}- \\
5(5.0)\end{array}$ \\
\hline
\end{tabular}

Note: $\#=$ standard deviation; ${ }^{*}$ selection number of the apomictic line, as seed plants-donors of seed embryos. 

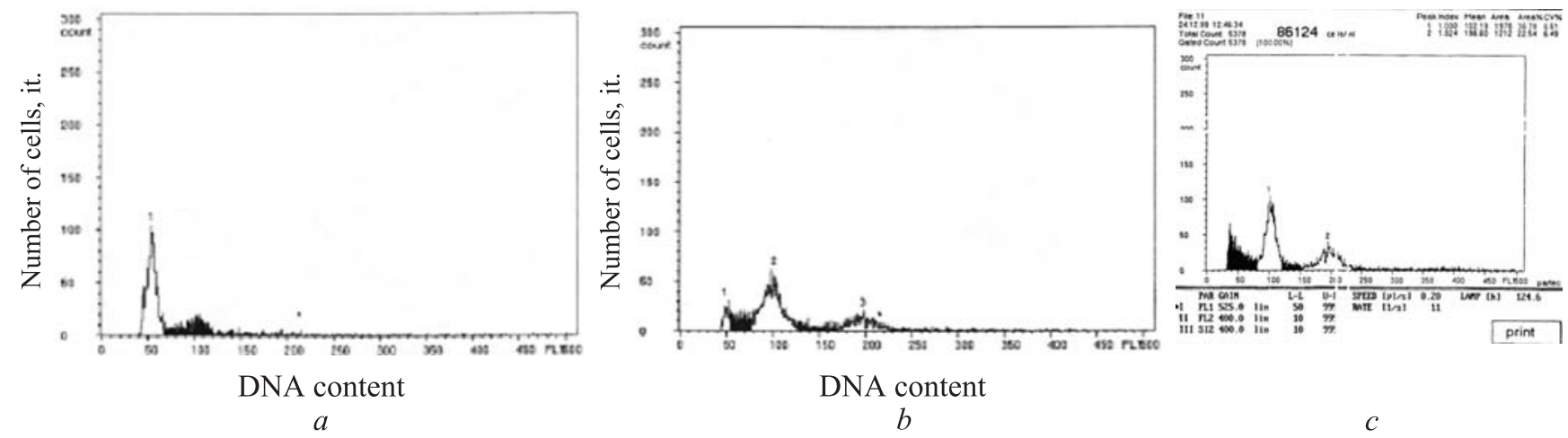

Fig. 5. Selected histograms of the distribution of polyploidy of interphase nuclei based on the total DNA content of those nuclei in regenerants of a sugar beet embryo culture under apomixis and CMS: $a$ - histograms of haploid shoots with the distribution of interphase nuclei on channels 50 and 100 in regenerants of apomictic line 13-138 $\mathrm{A}_{6}: 18$ p.5; $b$ - distribution of interphase nuclei of mixoploid regenerants on channels 50,100 and 200) in regenerants of alloplasmic line $\mathrm{B}_{6} \mathrm{CS}$ patula (Madeira) $\mathrm{A}_{2}: 18$ p.2; $c$ - histogram of diploids 100 and 200 in regenerants of apomictic line $13-136 \mathrm{~A}_{6}: 18$ p.5

[26], haploid shoots both with the recessive allele $\mathrm{r}-$ and the dominant allele $\mathrm{R}+$ responsible for anthocyanin staining in the hypocotyl, are regenerated in apomictic embryos from the cells of the embryo sac. The results of analyzing regeneration potential and variability by the genome ploidy level of the shoots, formed in the process of embryo culture and micropropagation, are presented in Table 2.

The variability in of the genome ploidy level of interphase nuclei as determined by their total DNA content

Table 3. The efficiency of the method of inducing haploids and mixoploids in the culture of apomictic embryos in selection materials with cytoplasmatic male sterility of different origin

\begin{tabular}{|c|c|c|c|c|c|c|c|}
\hline \multirow{3}{*}{$\begin{array}{l}\text { Origin of selection } \\
\text { numbers of apomictic } \\
\text { lines }\end{array}$} & \multirow{3}{*}{$\begin{array}{l}\text { Number of } \\
\text { apomictic } \\
\text { lines }\end{array}$} & \multirow{3}{*}{$\begin{array}{l}\text { No of } \\
\text { cultivated } \\
\text { embryos }\end{array}$} & \multicolumn{4}{|c|}{$\begin{array}{c}\text { Efficiency of generative parthenogenesis (number } \\
\text { and \%)* }\end{array}$} & \multirow{3}{*}{$\begin{array}{l}\text { Haploids } \\
\quad \mathrm{n} \text { and } \\
\text { mixoploids } \\
n, 2 n, 4 n \text { n } \\
\quad \text { and } \%\end{array}$} \\
\hline & & & \multicolumn{2}{|c|}{$n, 2 n^{* *}$} & \multicolumn{2}{|c|}{$n, 2 n, 4 n^{* * *}$} & \\
\hline & & & number & $\%$ & number & $\%$ & \\
\hline $\mathrm{B}_{3} \mathrm{CS}$ maritima (Greece) & p. 1 & 210 & 14 & 6.7 & 17 & 8.1 & (31) 14.8 \\
\hline $\mathrm{A}_{2}: 18$ & p. 2 & 150 & 5 & 3.3 & 16 & 10.6 & (21) 13.9 \\
\hline \multirow[t]{3}{*}{$\mathrm{B}_{4} \mathrm{CS}$ (Madeira) $\mathrm{A}_{2}: 18$} & p. 1 & 250 & 14 & 5.6 & 48 & 19.2 & (62) 24.8 \\
\hline & p. 2 & 75 & 6 & 8.0 & 6 & 8.0 & (12) 16.0 \\
\hline & p. 3 & 84 & 12 & 14.6 & 40 & 47.6 & (52) 62.25 \\
\hline \multirow{3}{*}{$\mathrm{B}_{3} \mathrm{CS}$ (Turkey) $\mathrm{A}_{1}: 18$} & p. 1 & 250 & 15 & 6.0 & 55 & 22.0 & (70) 28.0 \\
\hline & p. 2 & 171 & 14 & 8.2 & 22 & 12.9 & (36) 21.1 \\
\hline & p. 3 & 150 & 9 & 6.0 & 34 & 22.7 & (43) 28.7 \\
\hline \multirow[t]{2}{*}{$\mathrm{B}_{6} \mathrm{CS}$ (Madeira) $\mathrm{A}_{2}: 18$} & p. 1 & 175 & - & - & 10 & 5.7 & (10) 5.7 \\
\hline & p. 2 & 112 & - & - & 18 & 16.1 & (18) 16.1 \\
\hline \multirow[t]{3}{*}{$13-138 \mathrm{~A}_{6}: 18$} & p. 1 & 112 & 2 & 1.8 & - & - & (2) 1.8 \\
\hline & p. 5 & 215 & 8 & 3.7 & 11 & 5.1 & (19) 8.8 \\
\hline & p. 8 & 150 & 3 & 2.0 & 12 & 8.0 & (15) 10.0 \\
\hline \multirow{2}{*}{$13-136 \mathrm{~A}_{6}: 18$} & p. 4 & 105 & 7 & 6.7 & 7 & 6.7 & (14) 13.4 \\
\hline & p. 12 & 100 & 2 & 2.0 & 5 & 5.0 & (7) 7.0 \\
\hline
\end{tabular}

Note: *efficiency of haploid reduced parthenogenesis expressed as the percentage of shoots with haploid nuclei (50 un., 100 un.), (50 un., 100 un., 200 un.); ** haploids $n, 2 n$ are regenerated from the cells of embryo sac and the haploid status of the genome is maintained in the micropropagation; ***mixoploids $n, 2 n, 4 n$ are regenerants of reduced cells of the embryo sac due to endomitosis and somatic polyploidization under apomixis. 
in the regenerants of embryo culture in case of apomixis (both alloplasmic and CMS) is presented in selected histograms in Fig. 5.

Seed embryos from seed plants-donors, and apomictic embryos of apocarpous pollen free lines of sugar beet with selection numbers $13-136 \mathrm{~A}_{6}: 18$ and $13-138$ $\mathrm{A}_{6}: 18$ showed considerable $(8.8-16.1 \%$ on day 22$)$ shoot degeneration when cultivated in vitro (Table 2 ). The percentage of haploids fluctuated from 1.8 to $6.7 \%$ for pollen free lines of sugar beet and from 3.3 to $14.3 \%$ for alloplasmic lines with new sterile cytoplasm.

In the progeny with new sterile cytoplasm of the wild Beta patula, $8.6 \%$ of the embryos of line $\mathrm{B}_{6} \mathrm{CS}$ patula $\mathrm{A}_{2}: 18$ p.5 and $67.9 \%$ of $\mathrm{B}_{4} \mathrm{CS}$ patula $\mathrm{A}_{2}: 18$ p.3 produced shoots when cultivated for the first time.

The percentage of haploids of line $\mathrm{B}_{4} \mathrm{CS}$ patula $\mathrm{A}_{2}: 18$ p. 3 with recessive green $\mathrm{r}$ - color allele was $14.3 \%$. The diploids with the allele dominant red color $\mathrm{R}+$ were $32.1 \%$ for line $\mathrm{B}_{3} \mathrm{CS}$ maritima $\mathrm{A}_{1} 18 \mathrm{p} .2$, and for the p. 3 line this number was $17.3 \%$. Haploids were absent in most donors of apomictic R+ embryos with red hypocotyl in sugar beet.

Table 3 shows the efficiency of inducing haploids and mixoploids in the culture of apomictic embryos in selection materials with cytoplasmatic male sterility of different origin. The percentage of regenerants in pollen sterile lines of sugar beet with apomixis fluctuated from 1.8 to $10.0 \%$ in seed plants-donors of the embryo culture with selection number 13-138 $\mathrm{A}_{6}: 18 \mathrm{p} 1$ and from 7.0 to $13.4 \%$ in pollen free lines of sugar beet 13 $136 \mathrm{~A}_{6}: 18 \mathrm{p} 5$ and depended on genetic determination of apomictic reproduction of seeds in selection numbers, which defined the percentage of developed embryos and regenerated seed embryos in vitro, respectively.

According to Table 3, the percentage of mixoploids and haploids (combined by their origin from generative cells of the embryo sac) regenerants of line $\mathrm{B}_{3} \mathrm{CS}$ maritima $\mathrm{A}_{2}: 18$ was $13.9-14.8 \%$. The percentage of mixoploids and haploids for selection numbers with sterile cytoplasm from Beta maritima fluctuated from 21.1 to $28.7 \%$.

One of the main stages of creating homozygous lines in vitro is polyploidization and stabilization of the new lines by transferring the selected plants of these lines to cultural media using a polyploidizing substance, such as colchicine [17]. But in our research, when culturing apomictic embryos and their cloning for two-three passages on a cultural medium for sugar beet according to
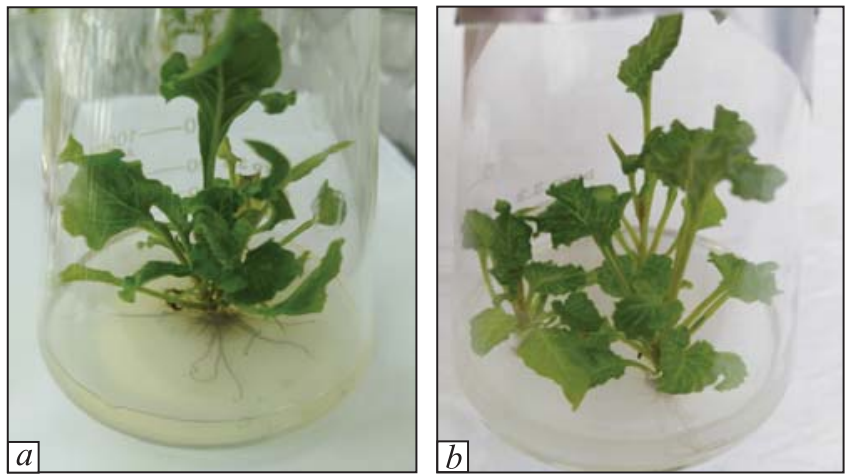

Fig. 6. $a-a$ rooted clone of homozygous line $2 \mathrm{~B}_{3} \mathrm{CS}$ maritima $\mathrm{A}_{1}: 18 ; b$ - alloplasmic line $2 B_{6} C S$ patula $\mathrm{A}_{2}: 18$, stabilized by the level of genome ploidy

Gamberg et al. (1968) (21) formula with the addition of BAP $0.3 \mathrm{mg} / 1$ and gibberellin $1 \mathrm{mg} / \mathrm{l}$, lines of dihaploids were isolated from all the investigated selection numbers of types of regenerants, either based on new sterile cytoplasm, or regenerants, based on sterile cytoplasm (Table 3) without the addition of colchicine.

Examples of the rooted clones of homozygous dihaploid lines are presented in Fig. $6(a)$.

The stabilizing selection of the developed shoots in vitro on the basis of ploidy resulted in a high regeneration capability and formation of morphologically developed clones, capable of rooting. The introduction of naphthyl acetic acid into the medium according to Gamberg et al. (1968) resulted in the successful (80$100 \%$ ) rooting of diploid clones of cultivated plants.

\section{DISCUSSION}

Embryogenetic stages of apomictic embryos of sugar beet have been determined in earlier studies [19, 23]. Both in the CMS line 13-138 $\mathrm{A}_{6}: 18 \mathrm{p} .1$ and alloplasmic lines $\mathrm{B}_{3} \mathrm{CS}$ maritima $\mathrm{A}_{2}: 18$ p. $1, B_{4} \mathrm{CS}$ patula $\mathrm{A}_{2}: 18,13-136$ p.5 embryos developed slower than those of the control haploid lines. Therefore, it is suggested to discriminate and select embryos for culturing already from day 12 , when most of them are in the globular stage.

When comparing four variations in growth hormones (cytokinins and auxins) and carbon source, the basal medium with $0.1 \mathrm{mg} / 1$ gibberellic acid, $2 \mathrm{mg} / 16 \mathrm{BAP}$, $0.5 \mathrm{mg} / 12.4 \mathrm{D}, 30 \mathrm{~g}$ saccharose, $10 \mathrm{~g}$ glucose, (medium no. 3 of Table 1) yielded the best results in direct regeneration in a culture of embryos within the range of $4.40 \pm 1.29$ for an alloplasmic line (13-138 $\mathrm{A}_{6}: 18$ p.1) and $23.3 \pm 3.45 \%$ for a CMS line (B CS maritima «Ts» $A_{2}: 18$ p.5.). An overall observation is that success 
of bringing embryos into culture depended mostly on the culture medium and to a lesser extent on the stage of embryo formation at the time of starting the cultivation.

When analyzing the ploidy level by fluorescent flow cytometry on total DNA of interphase nuclei, haploids $(\mathrm{R}+\mathrm{r}-)$ were detected and selected in regenerants of the $2^{\text {nd }}$ passage. The percentage of these obtained haploids depended on the genotype of sugar beet and alloplasmic line donors. Regenerants of apomictic embryos (which were gametophytic reduced apomictic) were found to be mixoploid (haploid, diploid, tetraploid in interphase nuclei) and may be used to obtain the lines of dihaploids. Mixoploids have been characterized earlier in somatic tissue of sugar beet $[14,18]$. Apomixis changes the way of seed production in many flowering plants, but it was found that apomictic progeny often has anomalies in the mechanism of mitosis and the result is the occurrence of endopolyploid, tetraploid cells, and cells of a higher level of ploidy [9, 27-29]. It was proven that under endopolyploidy there are changes both in the copies of the genome and genes in the cell and in the activity of genes [27].

In alloplasmic lines, the percentage $(62.2 \pm 5.3 \%)$ of haploid shoots in the suspension of leaf cells was the highest in comparison to all the other methods of inducing haploid parthenogamy in sugar beet. To our knowledge we are the first who have been able to produce haploid and mixoploid shoots during the first three-four passages in micropropagation without the use of polyploidizing substances such as colchicine. We believe that in future, the polyploidy status of regenerants should be further characterized and proven, using for example, molecular markers, in-situ hybridization or other relevant genetic molecular methods. At present our way of seed production in apocarpous pollen sterile lines of sugar beet is still in its infancy. But even now we can use facultative apomixis as a highly efficient way of inducing homozygous lines in vitro. The homozygous lines that we obtained may be used in further scientific studies and selection and breeding programs (including field studies) of sugar beet.

A large variability in the percentage of haploids and mixoploids (from 16.0 to $62.2 \%$ ) was determined for selection material with sterile cytoplasm of Beta patu$l a$, which, in this case, may depend on polyembryony in the selection number $\mathrm{B}_{4} \mathrm{CS}$ patula $\mathrm{A}_{2}: 18$.

In addition to environmental hazard, the introduction of $0.1-0.005 \%$ colchicine to the nutrient media for efficient polyploidization, the exposition of explants for
$48 \mathrm{~h}$ to this substance led to the necrosis of regenerant growth points and degeneration of up to $40 \%$ of experimental material. In addition, according to the researchers of polyploidization in sugar beet in vitro, the colchicination of haploids and doubling the number of chromosomes takes place in an insignificant number of clones, up to $38 \%$, but requires much labor and time of transplanting $[14,17]$.

\section{CONCLUSIONS}

A new approach to enhance the efficiency of technologies of producing homozygous lines in apomictic sugar beet lines by inducing embryo culture and differentiation of regenerant plants by gametophytic reduced parthenogenesis in culture in vitro without the use of colchicine is presented, with the following results:

- stable haploid regenerants from reduced parthenogenesis in alloplasmic lines, based on new sterile cytoplasm of Beta maritima and Beta patula, - for some selection numbers up to 62.2 and for pollen sterile lines of sugar beet only up to $13 \%$;

- ploidy stabilization of shoots (as determined by fluorescent flow cytometry) to diploid level and obtaining homozygous lines in the course of three-four passages in micropropagation was obtained for all tested lines without the use of colchicine, and was based on endomitosis under apomixis.

The scientific research, presented in the article, was conducted within the framework of a scientific task 27.00.01.05.F (No. 0116U000331) ASR «Creating competitive hybrids of sugar beet and elaborating technological methods of implementing their biological potential» with the financing of NAAS of Ukraine.

Вдосконалення технологій отримання стабільних

(ди)гаплоїдних регенерантів з ембріокультури селекційних матеріалів цукрових буряків

(Beta vulgaris) з апозиготичним способом репродукції насіння без використання колхіцину

Н. С. Ковальчук ${ }^{1}$, М. В. Роїк ${ }^{1}$, Я. М. Гадзало ${ }^{2}$, Т. М. Недяк ${ }^{1}$, О. А. Зінченко ${ }^{1}$

${ }^{1}$ Інститут біоенергетичних культур і цукрових буряків НААН вул. Клінічна, 25, Київ, 03110, Україна ${ }^{2}$ Національна академія аграрних наук, вул. Михайла Омеляновича-Павленка, 9, Київ, 01010, Україна

e-mail: sugarbeet@ukr.net,natalakovalcuk461@gmail.com

Мета. Оцінити ефективність індукції генеративного, редукованого партеногенезу та вдосконалити використання диференційного потенціалу ембріокультури при апо- 
зиготичному способі репродукції насіння селекційних матеріалів цукрових буряків 3 цитоплазматичною чоловічою стерильністю (ЦЧС), та виділити гомозиготні лінії (подвоєні гаплоїди) без дії поліплоїдизуючих речовин. Методи. Апоміктичний спосіб репродукції насіння у роздільноплідних пилкостерильних ліній з $B$. vulgaris subsp. vulgaris var. altissima (цукрових буряків) стерильною цитоплазмою Оуена і стерильними цитоплазмами від диких видів Beta maritima і Beta patula був забезпечений методом безпилкового режиму, в умовах просторової ізоляції і селекційно-тепличного комплексу Ялтушківської дослідно-селекційної станції (Ялтушки, Україна). Особливості ембріонального розвитку апоміктичних зародків вивчали для оцінки ефективного регулювання індукції експлантів in vitro, як донорів культури недозрілих ембріонів. Використано методи флуоресцентної цитофотометрії з комп'ютерними програмами Ploidy Analyser PA-2 («Partec GmbH», Німеччина, зараз Sysmex), для визначення рівня плоїдності та добору гаплоїдних і дигаплоїдних ліній in vitro. Розроблена генетична модель 3 використанням експресії морфологічних маркерних ознак ядерних генів антоціанового забарвлення (R+r-) рослин-регенерантів in vitro та визначення плоїдності для диференціації генеративним (редукованим) партеногенезом. Технологію підбору вибірки, яка враховує гормональний склад культурального середовища та рівень плоїдності геному, частоту вибірки та статистичний аналіз результатів визначали за використання відповідної статистики; відсоток регенерантів, індукованих різними типами морфогенезу та плоїдності in vitro, визначали разом 3 похибкою вимірювань для контролю точності підібраної вибірки (кількості насіннєвих зачатків). Результати. Підібрано склад культурального середовища № 3 на основі базового середовища згідно з Gamberg et al., 1968 (21) із введенням 6 БАП - 2 мг/л, 2,4 Д - 0,5 мг/л, гіберелової кислоти - 0,1 мг/л, що забезпечує пряму регенерацію пагонів $з$ ембріокультури, залежно від генотипу рослин-донорів від 4,4 до 23,3\%, індукцію і проліферацію калюсу від 4,0 до 10,0 \%. У десяти експериментальних номерів алоплазматичних ліній цукрових буряків відсоток гаплоїдних і міксоплоїдних пагонів у регенерантів 3 ембріокультури змінювався у межах 14,8$62,2 \%$ і перевищував показники, отримані іншими відомими способами гаплоїдної партеногамії, показники яких були у межах 3,79-6,25 \% для цукрових буряків. Висновки. Гомозиготні лінії та дигаплоїди було визначено і стабілізовано в процесі мікроклонального розмноження, під час якого диференціацію клонів проводили на основі загального вмісту ДНК в інтерфазному ядрі за використання гістограм, отриманих під час флуоресцентної проточної цитометрії на Partec Ploidy Analyser PA-II. Було виявлено, що середовище на основі макро- та мікросолей згідно з Gamberg et al., 1968 (21) є найефективнішим; воно забезпечувало принаймні част- ково успішну пряму регенерацію в культурі зародків в межах від $4.40 \pm 1.29$ до $23.3 \pm 3.45 \%$. Успіх прямої регенерації апоміктичного матеріалу в першу чергу залежав від складу використаного культурального середовища, і дещо менше - від стадій ембріогенезу 3 дня 12 до дня 32, диференційованих за періодом фіксації насіннєвих зародків, починаючи від початку цвітіння. Створено гомозиготні лінії без використання поліплоїдизуючих речовин завдяки спонтанному переходу частини клітин гаплоїдних рослин-регенерантів на вищий рівень плоїдності, що можна використовувати в селекції цукрових буряків. Генетичне визначення апоміктичного способу репродукції у алоплазматичних ліній і безпилкових ліній цукрових буряків, а також технології індукції дигаплоїдів дозволяють значно скоротити період інцухт-схрещувань для отримання гомозиготних ліній та створити унікальний матеріал для хромосомної інженерії та маркер-орієнтованої селекції з заданими комбінаціями генів у гомозиготному стані.

Ключові слова: апоміксис (апозиготія), гаплоїди, подвоєні гаплоїди, алоплазматичні лінії, Beta maritima, аналізатор плоїдності (АП) «Partec».

\section{Совершенствование технологий получения стабильных (ди)гаплоидных регенерантов из эмбриокультуры селекционных материалов сахарной свеклы (Beta vulgaris) с апозиготическим способом репродукции семян без использования колхицина}

Н. С. Ковальчук ${ }^{1}$, М. В. Роик ${ }^{1}$, Я. М. Гадзало ${ }^{2}$, Т. М. Недяк ${ }^{1}$, О. А. Зинченко ${ }^{1}$

${ }^{1}$ Институт биоэнергетических культур и сахарной свеклы УААН

ул. Клиническая, 25, Киев, 03110, Украина

${ }^{2}$ Национальная академия аграрных наук, ул. Михаила Емельяновича-Павленко, 9, Киев, 01010, Украина

e-mail: sugarbeet@ukr.net,natalakovalcuk461@gmail.com

Цель. Оценить эффективность индукции генеративного, редуцированного партеногенеза и морфоргенного потенциала эмбриокультуры при апозиготическом способе репродукции семян в селекционных материалах сахарной свеклы с цитоплазматической мужской стерильностью (ЦМС), для выделения гомозиготных линий (удвоенных гаплоидов) без воздействия полиплоидизирующих веществ. Методы. Апомиктический способ репродукции семян у раздельноплодных пыльцестерильных линий с S. vulgaris цитоплазмой Оуэна и новыми стерильными цитоплазмами от диких видов Beta maritima и Beta patula был обеспечен методом безпыльцевого режима в условиях пространственной изоляции и селекционно-тепличного комплекса Ялтушковской опытно-селекционной станции. Проведена идентификация и отбор семенных растений доноров не- 
зрелых зародышей по фенотипическим признакам ядерных генов стерильности (МС-0, МC-I, МС-II). Применены методики исследования стадий эмбрионального развития апомиктических зародышей для оценки эффективности регулирования индукции экплантов, как доноров культуры не зрелых эмбрионов за разными типами морфогенеза, зависимо от состава культуральных сред через прямую регенерацию и формирование калюсной ткани. Использованы методы флюорисцентной цитофометрии с компьютерными програмами Ploidy Analyser PA-2 («Parec GmbH», Германия), для определения уровня плоидности и отбора гаплоидных и дигаплоидных линий in vitro. Разработана генетическая модель с использованием экспрессии морфологических маркерных признаков антоциановой окраски $(\mathrm{R}+\mathrm{r}-)$ для дифференциации регенерантов по генеративному и соматическому эмбриогенезу. Для достоверности исследований и правильно подобранной выборки в зависимости от гормонального состава культуральных сред и уровня плоидности генома, использованные методики статистического анализа. Результаты. Подобран состав культуральной среды с введением 6 БАП 2мг/л, 2,4 Д 0,5 мг/л, гибберелловая кислота 0,1 мг/л, что обеспечивает прямую регенерацию побегов с эмбриокультуры, в зависимости от генотипа семенных растений-доноров от 4,4 до $23,3 \%$, индукцию и пролиферацию каллуса от 4,0 до 10,0 \%. Процент гаплоидных и миксоплоидных побегов в алоплазматических линиях значительно превышал количество растений, полученных другими известными способами индукции гаплоидной партеногамии у сахарной свеклы, и варьировал в пределах 16,$7 ; 24,8 ; 62,2 \%$. Выделенные гомозиготные линии, удвоенные гаплоиды в процессе культивирования и дифференциации клонов по содержанию ДНК в интерфазных ядрах на гистограммах (АП) «Рartec». Выводы. На примере апозиготических линий с ЦМС $S$. vulgaris типа сахарной свеклы и алоплазматических линий с новыми стерильными цитоплазмами от диких видов Beta Maritima и Beta patula, рассмотрены цитогенетические особенности генезиса клеток в культуре незрелых апомиктических зародышей, индуцированных in vitro на стадии развития эмбрионов 12, 20, 22 суток. Лучшей оказалась среда № 3 и обеспечивала прямую регенерацию в культуре незрелых зародышей в пределах $4,40 \pm 1,29$ и 23,3 \pm $\pm 3,45 \%$. По результатам экспериментальных исследований мы наблюдаем зависимость эмбриогенного потенциала прежде всего от генетической детерминации апозиготического способа репродукции семян у растений-доноров, а также состав культуральных сред и в меньшей степени от стадии эмбрионального развития зародышей. С учетом суммарного процентного соотношения гаплоидных растений и миксоплоидных с присутствием фракции гаплоидных интерфазных ядер на (АП) «Рartec», установлена эффективность индукции генеративного редуцированного партеногенеза в эмбриокультуры селекционных материалов сахарной свеклы с ЦМС и апомиксисом. Созданные гомозиготные линии без использования полиплоидизирующих веществ, благодаря спонтанному переходу части клеток гаплоидных растений-регенерантов на более высокий уровень плоидности для применения в селекцыионном процессе сахарной свеклы. В условиях генетической детерминации апомиктического способа репродукции семян при межвидовой гибридизации и использования новой технологии индукции линий удвоенных гаплоидов возможно значительно сократить срок инцухт-скрещиваний, трудозатратность полевых исследований и создать уникальный материал для использования результатов хромосомной инженерии, маркерориентированной селекции с заданными комбинациями генов в гомозиготном состоянии.

Ключевые слова: апомиксис (апозиготия), гаплоиды, удвоенные гаплоиды, сахарная свекла, аллоплазматические линии, Beta maritima, анализатор плоидности (АП) «Partec».

\section{REFERENCES}

1. Hand ML, Vit P, Krahulcová A, Johnson SD, Oelkers K, Siddons H, Chrtek JJR, Fehrer J, Koltunow AM. Evolution of apomixis loci in Pilosella and Hieracium (Asteraceae) inferred from the conservation of apomixislinked markers in natural and experimental populations. Heredity (Edinb). 2014;114(1):17-26. doi:10.1038/hdy. 2014.61.

2. Hojsgaard D, Klatt S, Baier R, Carman JG, Hörandl E. Taxonomy and biogeography of apomixis in Angiosperms and associated biodiversity characteristics. Crit. Rev. Plant Sci. 2014;33(5):414-27. doi:10.1080/073526 89.2014.898488.

3. Rodriguez-Leal D, Vielle-Calzada J-P. Regulation of apomixis: learning from sexual experience. Curr. Opin. Plant Biol. 2012;15:549-55. http://dx.doi.org// 10.1016/j. pbi.2012.09.005.

4. Okada T, Ito K, Johnson SD., Oelkers K, Suzuki G, Houben A, Mukai Y, Koltunow AM. Chromosomes carrying meiotic avoidance loci in three apomictic eudicot Hieracium subgenus Pilosella species share structural features with two monocot apomicts. Plant Physiol. 2011;157:1327-41. doi: https://doi.org/10.1104/pp.111. 181164.

5. Yamashita K, Nakazawa Y, Namai K., Amagai M, Tsukazaki H, Wako T, Kojima A. Modes of inheritance of two apomixis components, diplospory and parthenogenesis, in Chinese chive (Allium ramosum) revealed by analysis of the segregating population generated by back-crossing between amphimictic and apomictic diploids. Breed. Sci. 2012;62(2):160-9. doi:10.1270/jsbbs.62.160.

6. Naumova TN, Hayward MD, Wagenvoort M. Apomixis and sexuality in diploid and tetraploid accession of $\mathrm{Bra}$ - 
chiaria decumbens. Sex. Plant Reprod. 1999;12(1):4352. doi: https://doi.org/10.1007/s004970050170.

7. Szkutnik T. Apomixis in the sugar beet reproduction system. Acta Biol. Cracoviensia Series Botanica. 2011; 52(1):87-96. doi: 10.2478/v10182-010-0011-y.

8. Kashin AS, Tsvetova MI, Demochko YuA. Cytogenetic peculiarities of the genesis of apical meristem cells in case of gametophytic apomixis (with reference to autonomous Asteraceae apomicts). Cytol. Genet. 2011;45(2):85-96.

9. Naumova TN. Apomixis and amphimixis in flowering plants. Cytol. Genet. 2008;42(3):179-88.

10. Khan YJ, Choudhary R, Tyagi H, Singh AK. Apomixis: The molecular perspectives and its utilization in crop breeding. J. AgriSearch. 2015;2(3):153-61.

11. Maletskii SI, Maletskaya EI, Yudanova SS. Apozygous seed production in the system of the genus Beta (Chenopodiaceae) and Vavilov's homology series. Vavilovskiy zhurnal genetiki i selektsii, 2011;15(1):66-79. http:// www.bionet.nsc.ru/vogis/pict_pdf/2011/15_1/7.pdf

12. Bohomolov MA. Apomixis in sugar beet (Beta vulgaris L.). Review of domestic and foreign studies. Tekhnologia vysokikh urozhaev 2018;11:27-33. http://saharmag.com/ netcat_files/userfiles/other/Bogomolov.pdf

13. Yudanova SS. Mixoploidy and apozygoty in sugar beet. Sugar Tech, 2003;5:173-5. https://doi.org/10.1007/BF02943630.

14. Maletskaya EI, Yudanova SS, Maletskii SI. Haploids in apozygotic seed progenies of sugar beet (Beta vulgaris L.). Sugar Tech. 2009;11(1):60-64. doi:10.1007/s12355009-0010-z.

15. Bogomolov MA, Fedulova TP. Introgression of apomixis - a new way of creating sugar beet hybrids (Beta vulgaris L.). Sakharnaya svekla. 2018;(2):4-7. doi: 10.25802/SB.2018.02.13380.

16. Murovec J, Bohanec B. Haploids and doubled haploids in plant breeding. Plant Breed., 2012:87-106. doi: $10.5772 / 29982$.

17. Zhuzhzhalova TP, Podvigina OA, Znamenskaya VV, Vasil'chenko EN, Karpechenko NA, Zemlyanukhina OA. Sugar beet (Beta vulgaris L.) haploid parthenogenesis in vitro: factors and diagnostic characters. Agric. Biol. 2016;51(5):636-44. doi: 10.15389/agrobiology. 2016.5.636eng

18. Roik N, Kovalchuk N, Yatseva O. Apozygoty as a method of creating initial materials of sugar beet. Bull. Agric. Sci.2014;(6):45-7.http://agrovisnyk.com/oldpdf/visnyk 06_2014.pdf

19. Maletskii SI, Yudanova SS, Maletskaya EI. Analysis of epigenomic and epiplastome variability in the haploid and dihaploid sugar beet (Beta vulgaris L.) plants. Agric. Biol. 2015;50(5):579-89. doi:10.15389/agrobiology. 2015.5.579.

20. Levites E, Kirikovich $S$. The heteroallicity instead of heterozygosity in haploids of sugar beet Beta vulgaris L. Bull. Sci. Pract. 2017;(5):32-8. https://www.academia.edu/33122753/Bulletin_of_Science_and_Practice_5_2017.pdf.

21. Gamborg OL, Miller RA, Ojima K. Nutrient requirement of suspension cultures of soybean root cells. Exp. Cell Res. 1968;50(1):151-8. doi: 10.1016/00144827(68)90403-5.

22. Roik M, Kovalchuk N, Lysenk V., Himich N. Apozygotism as a new method of enrichment of gene pool of sugar beet. Bull. Agric. Sci. 2015;(11): 49-52. http://agrovisnyk.com/pdf/ua_2015_11.pdf. (in Ukrainian).

23. Kovalchuk N, Roik N, Potapovich $O$. New sterile cytoplasms from wild beet Beta vulgaris SSP maritima L. from Greece and Turkey. Sakharnaya svekla, 2013;4:315. http://sugarbeet.ru/pdf/2013/042013.pdf\#page=31

24. Shyryaeva EI. Methodological instructions regarding cytoembryological studies in breeding of sugar beet. Kyiv: VNIS, 1984:62 p.

25. Bilous VO, Ilenko II, Oliynyi NA, Pavlovska LL, Berdyshev $O G$. To the method of obtaining haploid plants of sugar beet from isolated unfertilized seed bud. Sugar beet. 2006;(6):12-3.

26. Pat. No. 104295. Ukraine. MPK (2016.01) A01H 4/0. Method of obtaining haploid and dihaploid lines of sugar beet based on apozygoty and cytoplasmatic male sterility/ Roik MV, Yatseva OA, Nediak TM, Potapovych OA, Kachalovska SO. - No. u 2015 06234; appl. 24.06.2015 publish. 25.01.2016.

27. Lukaszewska E, Sliwinska E. Most organs of sugarbeet (Beta vulgaris L.) plants at the vegetative and reproductive stages of development are polysomatic. Sex Plant Reprod. 2007;20:99-107. https://doi.org/10.1007/ s00497-007-0047-7.

28. Gmurman VE. Theory of probabilities and mathematical statistics. M.: Vysshaya shkola, 1999:479 p.

29. Kunakh VA, Adonin VI, Ozheredov SP, Blume YaB. Mixoploidy in wild and cultivated species of Cruciferae capable of hybridizing with rapeseed Brassica napus. Cytol. Genet. 2008;42(3):204-9. doi: 10.3103/ S0095452708030079. 